\title{
Beoefen Praktiese Teologie altyd met die oog op God
}

\section{Book Title: \\ Met die oog op God \\ Book Cover: \\ Met die oog op God

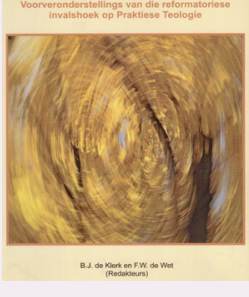 \\ Authors: \\ B.J. de Klerk \\ F.W. de Wet (eds.) \\ ISBN: \\ 978-0-86955-206-3}

Publisher:

Potchefstroom Theological Publications, 2013, R170*

*Book price at time of review

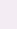

\section{Review Title:}

Beoefen Praktiese Teologie altyd met die oog op God

Reviewer:

Gerhardus J. Niemann ${ }^{1}$

\section{Affiliation:}

${ }^{1}$ Faculty of Theology, North-West University, Potchefstroom Campus, South Africa

Email:

dsgerhardn@gmail.com

Postal address:

PO Box 154, Cullinan 1000, South Africa

How to cite this book review: Niemann, G.J., 2014, 'Beoefen Praktiese Teologie altyd met die oog op God', In die Skriflig/In Luce Verbi 48(1), Art. \#1801, 2 pages. http://dx.doi.org/10.4102/ ids.v48i1.1801

\section{Read online:}

Hierdie is ' $n$ besonderse boek wat 'n groot rol binne die reformatoriese Praktiese Teologie kan en behoort te speel. Na my mening oorskadu hierdie boek huidige boeke in dieselfde veld. Dit is die mees volledige boek oor Praktiese Teologie wat ek tot op hede onder oë gehad het. Dit bied 'n moderne omskrywing van die rol en doel van die beoefening van Praktiese Teologie, en poog om die metateoretiese faktore van die praktiese teologiese wetenskapsbeoefening uit te spel en te verwoord. Die boek is uiters aktueel en geweldig verrykend. Die skrywers daag lesers uit om wyer te dink oor die praktyk van geloof en hoe ons uiting gee aan ons geloof in die moderne en veranderende wêreld. Die skrywers gee 'n omvattende uiteensetting van die huidige strome waarbinne die praktiese teologiese wetenskapsbeoefening plaasvind. Teenoor hierdie denkskole word die reformatoriese standpunt omvattend gespel.

Die skrywers fokus hulle aandag spesifiek op verantwoordelike en konsekwente wetenskapsbeoefening. Wat die boek besonders maak is dat die skrywers die praktiese werklikheid van die evangelie en die leefwêreld van die gelowige in die beoefening van Praktiese Teologie goed verreken. Hulle poog om die skynbare 'diskrepansie' tussen die gereformeerde werklikheidsbeskouing en die praktiese beoefening van geloof aan te spreek. Die skrywers plaas die praktiese teologiese wetenskapsbeoefening binne die raamwerk van die teologiese wetenskap en wetenskap in die algemeen. Hulle kyk ook in watter opsigte Praktiese Teologie verskil of aansluiting kan vind by ander dissiplines op dieselfde navorsingsgebied.

Hierdie boek bied 'n wonderlike perspektief op die probleme waarmee predikante worstel, spesifiek hoe om die werklikheid van die gelowige en die werklikheid van God bymekaar te bring. Die boek help lesers om hulle te oriënteer met betrekking tot hulle eie wêreldbeskouing, werklikheidsbeskouing en wetenskapsbeoefening.

Die hermeneutiese model wat die skrywers bied vir die inrigting van Praktiese Teologie bied 'n werkbare model vir enige navorsing wat in hierdie vakgebied moet plaasvind. Hierdie navorsingsmiddel bied 'n deeglike metodologie wat vanuit die solo scriptura benadering voortvloei. Die voorgestelde model vind sy vertrekpunt primêr vanuit die verbondskommunikasie tussen die handelende God en die handelende mens.

Elke medewerker aan hierdie boek bied 'n besonderse insig en kennis vanuit hulle fokusareas. Enige leser sal die diepgaande kennis en ervaring van hierdie kundiges waardeer en verrykend vind:

- Prof. B.J. De Klerk beskryf vanuit sy besondere insig die rol van die liturgie as sigbare handelinge van die kerk. Hy verreken ook die moderne liturgiese benaderings en die rol van die veranderende konteks waarmee die liturg rekening moet hou. Hy staan ook 'n deel af aan die uiterse relevante 'verbruikerskultuur' wat in die liturgiese handelinge posgevat het. Hy beskryf op 'n mooi en helder manier hoe die liturgie as gebruiklikheidsdimensie in die werklikheidsdimensie van die menslike handelinge wat deur die goddelike werking van die Woord en Gees, bepaal word. Verder spel hy die wese van die reformatoriese liturgie op 'n verrykende wyse uit.

- Op die gebied van die Homiletiek omskryf Prof. F.W. De Wet en Prof. H.J.C. Pieterse die verantwoordelikheid van die prediker om die evangelie met oortuiging te preek. Hulle lê klem op die noodsaak dat die navorser die konteks van, en wendings in die denkklimaat en kultuur waarin die wetenskaplike taak uitgeoefen word, moet verreken. Verder bied hulle ook voorbeelde van hoe 'n navorsingsprojek in die Homiletiek kan plaasvind, met besondere fokus op die belangrikheid van profetiese prediking in die konteks van armoede.

- Prof. G. Breed bied op die gebied van gemeentebediening, jeug- en kinderbediening asook pastorale wetenskap 'n besondere waardevolle insig vir die predikant wat gekonfronteer

Copyright: @ 2014. The Authors. Licensee: AOSIS OpenJournals. This work is licensed under the Creative Commons Attribution License. 
word met postmoderne denke van lidmate. Hy fokus op hoe die gemeente vanuit 'n reformatoriese werklikheidsbeskouing ten volle as liggaam van Christus kan funksioneer. Hy gebruik die metafoor: 'Die kerk as beeld van God'. Hierdie metafoor stel die mens in 'n werksverhouding tot God; dit bring die mens in ' $n$ intieme persoonlike verhouding met God; laat die kerk in verwagting van die verheerlikte koning leef; en getuig van God as die Een wat die kerk tot stand bring en onderhou. Wat die pastoraal betref bied hy die omskrywing van die taak van die navorser in dié gebied op 'n besonderse wyse.

- Laastens bied Prof. R.S. Letšosa op die gebied van die Kategetiek 'n nuwe en verrykende standpunt van hoe die Kategese eerder benader moet word as 'n 'lewewekkende' proses om die probleme wat die tradisionele Kategese mee worstel te oorbrug.
Die boek is baie logies uiteengesit en maak dit vir lesers maklik om hulleself binne die struktuur van die boek te plaas deurdat die skrywers 'n eenvoudige diagram aan die begin van elke afdeling geplaas het. Elke fokusgebied in die Praktiese Teologie kom sistematies aan die orde.

Hierdie is 'n boek wat deel moet uitmaak van persone of studente wat hulle in die veld van Praktiese Teologie bevind. Die boek sal ook van groot waarde wees vir enige predikant wat met die praktyk van teologie te doen het, hetsy Liturgiek, Homiletiek, Gemeentebediening, Kinder- en Jeugbediening, Pastorale wetenskap of Kategetiek. Hierdie boek se waarde lê nie net in die Praktiese Teologie nie maar is van groot waarde vir reformatoriese teologie in die algemeen. Ek beveel hierdie boek aan vir elke predikant en navorser in die Praktiese Teologie. Ek glo dat hierdie boek 'n groot impak sal hê op die wyse waarop toekomstige navorsing in Praktiese Teologie sal geskied. 